\title{
Effect of Tropical Algae as Additives on Rumen in Vitro Gas Production and Fermentation Characteristics
}

\author{
Baptiste Dubois $^{1}$, Nigel W. Tomkins ${ }^{2}$, Robert D. Kinley ${ }^{2}$, Mei Bai ${ }^{2}$, Scott Seymour $^{3}$, Nicholas A. Paul ${ }^{3}$, \\ Rocky de $\mathrm{Nys}^{3}$ \\ ${ }^{1}$ AgroParisTech, 16 rue Claude Bernard, Paris, France; ${ }^{2}$ CSIRO, Livestock Industries, Australian Tropical Sciences Innovation Pre- \\ cinct, James Cook Drive, James Cook University, Townsville, Australia; ${ }^{3}$ School of Marine and Tropical Biology, James Cook Uni- \\ versity, Townsville, Australia. \\ Email: rob.kinley@csiro.au
}

Received October $17^{\text {th }}, 2013$; revised November $21^{\text {st }}, 2013$; accepted December $4^{\text {th }}, 2013$

Copyright (C) 2013 Baptiste Dubois et al. This is an open access article distributed under the Creative Commons Attribution License, which permits unrestricted use, distribution, and reproduction in any medium, provided the original work is properly cited.

\begin{abstract}
Algae have become an area of intensive research in many fields of study. Areas of application are becoming increasingly diverse with the advent of technologies particularly in the mass production of algae biomass. Algae contain complex bioactive compounds and these are gaining importance in emerging technologies with nutritional and environmental applications. In this study, a preliminary investigation evaluated 15 species of algae from the major categories of marine and fresh water algae for their potential as inclusions in ruminant diets for management of greenhouse gas emissions. It was hypothesized that algae would positively affect rumen fermentation and gas production while reducing methane production. The hypothesis was tested using an Ankom automated gas monitoring system and rumen fluid from Bos indicus steers fed tropical forage diets. The results were variable between algae species with some showing a significant reduction in total gas and methane production, with others increasing gas and fermentation. The red and brown algae stand out as having potential for greenhouse gas mitigation with the brown alga Cystoseira having the most prominent effect. The effects observed on fermentation may be manipulated through dosage management and beneficial effects could be potentially maximized by preparing combinations of algal supplements. It has been demonstrated in this study that algae have the potential to assist in rumen fermentation management for improved gas production, and greenhouse gas abatement.
\end{abstract}

Keywords: Algae; Enteric Gas; Macroalgae; Methane; Rumen; Seaweed

\section{Introduction}

In northern Australia, cattle are managed under extensive pastoral conditions dominated by native grasses [1], and animal productivity is lower than in temperate regions where pasture improvement and intensive management are commonplace [2]. Implementing practices to reduce the environmental impact of livestock systems across northern Australia, while maintaining a viable level of productivity, is challenging [3]. However, when feed supplementation is incorporated to improve ruminant production then employing additives that have an effect on greenhouse gas production would be beneficial for individual producers and the industry. A number of feed additives such as halogenated analogues [4], monensin [5] and a range of plant compounds such as tannins [6], saponins [7], essential oils [8,9], and various secondary me- tabolites [10] have been demonstrated to have potential in reducing greenhouse gas emission from livestock production systems, but in most part it's difficult to administer across large herds which are managed in extensive environments.

Algae exist in many forms and can be broadly classified on size (micro or macroalgae), and photosynthetic and accessory pigments (green, red or brown algae). Both marine and freshwater algae have been used in human nutrition, cosmetics, and pharmaceutical products and have the potential to be used as a supplement for livestock feeds [11]. Secondary metabolites with antimicrobial activity have been identified in green, red and brown algae [1214]. Other species tend to have anti-viral, antioxidant, or anti-inflammatory properties that may be used to manipulate livestock health and productivity. Specifically, $A s$ cophyllum nodosum has received attention for application 
in ruminant diets and effects on greenhouse gas production [15], but few papers describe the potential in a range of species of algae. Further work is required to screen numerous algae species to study the relationship between composition and effective fermentation characteristics. In vitro gas production techniques have been improved and applied to study fermentation kinetics relative to feed composition [16-19]. Consequently in vitro techniques can allow for rapid screening of a large number of feed additives that may have effects on gas production.

The objective of this study was to first rank the capability of fifteen tropical species of algae to influence in vitro gas production when incubated with a tropical grass (Chloris gayana) as the primary substrate and then assess dose response effects of selected algae species on in vitro gas production and fermentation characteristics using $\mathrm{pH}$ and methane concentration as proxy indicators.

\section{Materials and Methods}

\subsection{Selection and Preparation of Algae}

The algal species used in this study (Table 1) were se- lected due to their natural abundance in local aquaculture systems or intertidal reefs around Townsville, QLD, Australia, and their potential to be cultured under controlled conditions.

Seven of the algae used in this study (Caulerpa lentillifera, C. taxifolia, Cladophora patentiramea, Ulva sp 3. , Ulva ohnoi, Derbesia tenuissima and Oedogonium sp.) were maintained as isolated species at James Cook University, QLD, Australia. Tarong polyculture, a polyculture of freshwater microalgae, was sourced from MBD Energy Ltd., Townsville, QLD. The remaining five species of algae were collected from natural sources near Townsville, QLD.

The marine macroalgal biomass used in this study was initially washed in clean, fresh seawater for 2 minutes to minimize the amount of fouling organisms and silt and then rinsed thoroughly in dechlorinated freshwater for 1 minute to remove residual salt. Freshwater macroalgae were thoroughly rinsed in dechlorinated water immediately after collection. Washed algal biomass was placed in $100 \mu \mathrm{m}$ mesh for excess water removal by centrifuge

Table 1. Chemical composition of the 15 species used this study (g/kg DM unless stated otherwise).

\begin{tabular}{|c|c|c|c|c|}
\hline Algae species & $\mathrm{OM}^{\mathrm{C}}$ & $\mathrm{CP}^{\mathrm{D}}$ & $\mathrm{NDF}^{\mathrm{E}}$ & $\begin{array}{c}\mathrm{GE}^{\mathrm{F}} \\
(\mathrm{MJ} / \mathrm{kg} \mathrm{DM})\end{array}$ \\
\hline \multicolumn{5}{|l|}{ Green algae } \\
\hline Caulerpa lentillifera & 450.6 & 146.2 & 219.5 & 13.24 \\
\hline Caulerpa taxifolia & 730.2 & 264.7 & 458.4 & 16.02 \\
\hline Cladophora coelothrix & 751.5 & 401.2 & 320.1 & 11.99 \\
\hline Ulva ohnoi $^{1}$ & 826.6 & 440.9 & 297.2 & ND \\
\hline Cladophora patentiramea & 721.7 & 274 & 276.9 & 16.81 \\
\hline Ulva sp. $3^{1}$ & 816.7 & 381.6 & 218.5 & ND \\
\hline Derbesia tenuissima & 900.2 & 445.9 & 276.9 & 18.29 \\
\hline \multicolumn{5}{|l|}{ Red algae } \\
\hline Halymenia floresii & 798.5 & 314.9 & 269.6 & 11.85 \\
\hline Hypnea pannosa & 436 & 133.9 & 126.6 & 6.96 \\
\hline \multicolumn{5}{|l|}{ Brown algae } \\
\hline Cystoseira trinodis & 669.3 & 111.9 & 311.3 & 11.45 \\
\hline Padina australis & 554 & 103.6 & 360 & ND \\
\hline Dictyota sp. & 622.7 & 124.1 & 549.4 & ND \\
\hline \multicolumn{5}{|l|}{ Freshwater algae } \\
\hline Cladophora vagabunda & 579.7 & 109 & 399 & 18.32 \\
\hline Oedogonium sp. ${ }^{2}$ & 884.2 & 340 & 577.2 & 19.05 \\
\hline Tarong polyculture & 878 & 205.8 & 9.6 & ND \\
\hline
\end{tabular}

${ }^{\mathrm{A}}$ Relative proportion of wet algae to dry material $(\%) ;{ }^{\mathrm{B}}$ Dry matter; ${ }^{\mathrm{C}}$ Organic matter; ${ }^{\mathrm{D}}$ Crude protein; ${ }^{\mathrm{E}}$ Neutral detergent fibre; ${ }^{\mathrm{F}}$ Gross energy; ${ }^{1}$ Lawton et al. $2013 \mathrm{a}$ [24]; ${ }^{2}$ Lawton et al. 2013b [25]. 
at $1000 \mathrm{rpm}$ for 6 minutes in a commercial washing machine and then stored at $-10.0^{\circ} \mathrm{C}$. Prior to the experiments algae were freeze dried in a SP Industries VirTis $\mathrm{K}$ bench top freeze-drier (Warminster, PA). Dried material was stored in sealed poly bags at $-10.0^{\circ} \mathrm{C}$.

\subsection{Donor Animals and Preparation of Rumen Fluid Inoculum}

Rumen fluid was obtained from two rumen fistulated Brahman (Bos indicus) steers $(505 \pm 7 \mathrm{~kg})$ preconditioned ad libitum for two weeks with Rhodes grass $(\mathrm{Ch}$ loris gayana) hay typical of feeding in tropical QLD, Australia. The Rhodes grass contained on a $\mathrm{g} / \mathrm{kg}$ dry matter (DM) basis: organic matter (OM), 920; crude protein (CP), 107; neutral detergent fibre (NDF), 672; and acid detergent fibre (ADF), 467. The animals were maintained according to the guidelines of the Australian Code of Practice for the care and use of Animals for Scientific Purposes [20].

Rumen digesta was collected (1.5 L from each steer) with a manual suction apparatus into insulated, preheated $\left(39^{\circ} \mathrm{C}\right)$ thermal flasks according to [21]. Fibrous material from the rumen mat from forward, posterior, and lateral regions was included at approximately $10 \%$ of the $3 \mathrm{~L}$ collection volume. The pooled rumen fluid was blended at high speed for 30 seconds to ensure solid phase associated bacteria were distributed throughout the inoculum [22] and filtered through a $1 \mathrm{~mm}$ sieve and maintained anaerobic under a stream of $\mathrm{N}_{2}$.

\subsection{Experimental Design}

In experiment 1 four consecutive incubations were conducted to screen each species of algae for their effects on ruminal fermentation when $0.20 \mathrm{~g}$ (OM basis) of freeze dried algae of each species was incubated for $48 \mathrm{~h}$. A substrate was prepared with $1.00 \mathrm{~g} \mathrm{OM}$ of the previously described Rhodes grass. Each incubation set was completed with: 1) negative control containing only $1.00 \mathrm{~g}$ of Rhodes grass as substrate; 2) positive control $(\mathrm{n}=2)$ containing $1.00 \mathrm{~g}$ of the substrate plus $0.02 \mathrm{~g}$ of soybean OM (OM 920, CP 558, and NDF $190 \mathrm{~g} / \mathrm{kg}$ DM respectively), and also containing $0.18 \mathrm{~g}$ of sorghum (OM 987, CP 120, NDF $88.7 \mathrm{~g} / \mathrm{kg}$ DM respectively). Blank incubations $(\mathrm{n}=2)$ were also included.

For experiment 2 the gas production data obtained from experiment 1 combined with the composition and bioactive properties of the algae were used to select four species for assessment of dose response. For each of the selected algae (C. taxifolia, C. trinodis, Oedogonium sp. and Tarong polyculture) five doses $(0,20,40,80,160$ $\mathrm{mg} \mathrm{OM}$ ) were added to $1.00 \mathrm{~g}$ of the substrate assessed in $72 \mathrm{~h}$ incubations in quadruplicate in a Latin square design under conditions described for experiment 1 . Each incubation also included blanks $(\mathrm{n}=2)$ and the positive controls $(\mathrm{n}=2)$ as described for experiment 1 . Gas production, fermentation lag time, final $\mathrm{pH}$, and final headspace $\mathrm{CH}_{4}$ concentration were monitored.

\subsection{In Vitro Incubation}

All materials comprising the substrates were oven-dried and passed through a $1 \mathrm{~mm}$ sieve, and in vitro incubation was achieved using standard methodology $[17,19,23]$. Gas production, fermentation lag time, and final $\mathrm{pH}$ were monitored. Incubations and gas monitoring were completed with an ANKOM Technology (Macedon, NY) in vitro cumulative gas production system fitted with pressure transducers and gas sample collection ports. Filtered rumen inoculants were mixed with $39^{\circ} \mathrm{C}$ anaerobic buffer solution (Kansas state buffer) $[16,26]$ at 25 and $100 \mathrm{~mL}$ respectively, in pre-warmed $\left(39^{\circ} \mathrm{C}\right) 250 \mathrm{~mL}$ Schott (Mainz, Germany) bottles. The treatment incubations contained $1.0 \mathrm{~g}$ of substrate $\mathrm{OM}$, and $0.20 \mathrm{~g}$ of algae additive and were prepared as previously described.

Bottles were sealed under a $\mathrm{N}_{2}$ atmosphere and incubated at $39^{\circ} \mathrm{C}$ in Ratek (Boronia, Australia) model OM11 orbital mixer-incubators. Gas pressure was measured every 60 seconds and cumulative pressure recorded every 20 minutes for $48 \mathrm{~h}$ in experiment 1 , and $72 \mathrm{~h}$ in experiment 2.

\subsection{Analytical Methods}

Table 1 shows the chemical composition of the fifteen species of algae screened in this study. Dry matter of each species of algae and material used in the fermentation substrate was measured at $105^{\circ} \mathrm{C}$ to constant weight. Organic matter was measured by loss on combustion at $550^{\circ} \mathrm{C}$ for $8 \mathrm{~h}$. Gross Energy (GE) content was determined using a Parr Instrument Company (Moline, IL) Model 1108 bomb calorimeter. Neutral detergent fibre (aNDFom) was measured using a Foss (Hilleroed, Denmark) FiberCap 2023 fibre analyzer. Crude protein and total nitrogen content was determined using a LECO (St. Joseph, MI) CHN628 series nitrogen analyzer. Methane concentration in headspace gas samples collected in 10 $\mathrm{mL}$ Labco Exetainer vials were measured by gas chromatography on a Shimadzu (Koyto, Japan) GC-2010, equipped with a Carbosphere 80/100 column and a Flame Ionization Detector (FID).

\subsection{Calculations}

To estimate kinetic parameters of total gas production, gas production values were corrected for the amount of gas produced in the blank and corrected values were fitted with time using the non linear curve fitting procedure in Genstat [27] to a modified sigmoid model of Gompertz as described by Bidlack and Buxton [28] which was recommended for gas production systems by Lavrencic 
et al. [29] and Noguera et al. [30].

$$
y=A e^{-B e^{-C t}}
$$

where $y$ is the cumulative total gas production $(\mathrm{mL}), A$ is the maximal gas production $(\mathrm{mL} / \mathrm{g}), B$ is the lag period before exponential gas production starts (h), $C$ is the specific rate of gas production $(\mathrm{mL} / \mathrm{h})$ and $\mathrm{t}$ is elapsed time (h). Additionally the point of inflection (h-infl) was calculated as $\ln (B) / C$.

In this model it is assumed that gas production is proportional to the amount of metabolic end products produced during bacterial growth [31] and as a consequence gas production curves resemble the sigmoidal growth curves of bacteria grown in batch culture [32]. The first part of the curves describes the faster gas production rate at the beginning resulting from fermentation of easily degradable material and the second phase where slowly degradable material is fermented [29].

\subsection{Statistical Analysis}

Data from each experiment were analyzed independently. For experiment 1 gas production values from three incubations were analyzed using an analysis of variance for main effect of treatment (algae species) with replication in time considered as a random effect [33]. The results from experiment 2 were analyzed as a factorial design (4 additives $\times 5$ doses $\times 4$ replicates ) using the SAS PROC GLM procedure [33], according to the following statistical model:

$$
Y_{i j k}=\mu+A_{i}+D_{i}+(A \times D)_{i j}+\epsilon_{i j k}
$$

where $Y_{i j k}$ represents the value of each individual observation, $\mu$ is the average, $A_{i}$ is the effect of the $i$ th algae additive, $D_{j}$ is the effect of the $j$ th dose of the additive, and $\epsilon_{i j k}$ the residual error.

\section{Results}

\subsection{Chemical Composition of the Algae}

Green algae generally had higher OM content than red and brown algae except for Caulerpa lentillifera (Table 1). There were some species with low OM content $(<600$ $\mathrm{g} / \mathrm{kg} \mathrm{DM}$ ) and all the algae species tested had lower OM content than Rhodes grass used as the basis of the feed substrate $(920 \mathrm{~g} / \mathrm{kg} \mathrm{DM})$. Compared to the Rhodes grass (CP at $107 \mathrm{~g} / \mathrm{kg} \mathrm{DM}$ ), all species and, among these, particularly the green species (some $>400 \mathrm{~g} / \mathrm{kg} \mathrm{DM}$ ), were high in CP. Brown species were generally lower in $\mathrm{CP}$ $(<125 \mathrm{~g} \mathrm{CP} / \mathrm{kg} \mathrm{DM})$ compared to the other types. Derbesia tenuissima, Cladophora vagabunda and Oedogonium sp. had the highest levels of gross energy $(>18 \mathrm{MJ} / \mathrm{kg}$ DM). Hypnea pannosa demonstrated the lowest gross energy (6.96 MJ/ kg DM). Neutral detergent fibre contents varied widely among species, ranging from NDF
9.6 to $577.2 \mathrm{~g} / \mathrm{kg}$ DM. All the algae had lower NDF contents than the grass $(672 \mathrm{~g} / \mathrm{kg} \mathrm{DM})$. Tarong polyculture had a nearly nonexistent level of fibre $(9.6 \mathrm{~g} / \mathrm{kg} \mathrm{DM})$.

\subsection{Effects of Algal Species on in Vitro Fermentation Characteristics}

The effect of species of algae was prominent $(\mathrm{P}<0.001)$ for all fermentation variables and there were significant differences between algae species and types (Table 2 and Figure 1). All species except Cladophora coelothrix, Padina australis, Cladophora vagabunda and Oedogonium sp. had a significantly lower $(\mathrm{P}<0.05)$ asymptotic gas production $(A)$ than the control incubations (no algae). Dictyota sp. demonstrated the lowest blank corrected gas production with a $35.5 \mathrm{~mL}$ emission after 48 of incubation.

There was no significant change in gas production lag time $(B)$ at initiation of fermentation between algae treatments and control. However the negative control had the shortest overall lag time that was significantly lower than Dictyota sp. The wide range of lag times prevented significance between the longest lag time (Dictyota sp.) and the positive controls. In comparing species of algae, $\mathrm{Cla}$ dophora coelothrix, Derbesia tenuissima, Cladophora vagabunda and Oedogonium sp. demonstrated significantly higher asymptotic gas production $(\mathrm{P}<0.05)$ levels compared to the other algae.

Gas production varied for algae species and differences increased with length of time in fermentation (Figure 1). The greatest differences from control were observed with species of marine red and brown algae (Figures 1(a) and (b)). Some of the marine green algae and freshwater algae also demonstrated gas reduction while others were not significantly affected by algae inclusion (Figures 1(c) and (d)).

Most of the fermentation parameters were influenced $(\mathrm{P}<0.001)$ by algae species and dosage of algae, and the effect of the dose varied with species and the interaction between species and dose was significant $(\mathrm{P}<0.001$; Table 3). Asymptotic gas production decreased with increasing dose of Cystoseira trinodis. A similar trend was observed with Caulerpa taxifolia except for the highest dose. The addition of Tarong polyculture and Oedogonium sp. had little effect on total gas with increasing dose. There was little effect on lag time with increasing dose of algae for any of the select species.

The $\mathrm{pH}$ remained consistent between algae species in the range of $6.06-6.34$, and only minimal changes were demonstrated. Overall, the control had the lowest measured $\mathrm{pH}$ post fermentation (6.03), likely due to the addition of highly fermentable soybean and sorghum to the substrate producing slightly more acids during microbial degradation.

The headspace $\mathrm{CH}_{4}$ concentration was measured to 
Table 2. Effects of 15 species of algae on rumen fermentation characteristics in vitro over $\mathbf{4 8}$ hours.

\begin{tabular}{|c|c|c|c|}
\hline \multirow{2}{*}{ Algae species } & \multicolumn{2}{|c|}{ Gas production parameters } & \multirow{2}{*}{$\mathrm{pH}$} \\
\hline & $\mathrm{A}($ gas $\mathrm{mL})$ & B (lag h) & \\
\hline \multicolumn{4}{|l|}{ Green algae } \\
\hline Caulerpa lentillifera & $41.2^{\mathrm{D}}$ & $4.00^{\mathrm{AB}}$ & $6.15^{\mathrm{CDE}}$ \\
\hline Caulerpa taxifolia & $45.7^{\mathrm{D}}$ & $2.46^{\mathrm{ABC}}$ & $6.19^{\mathrm{BCDE}}$ \\
\hline Cladophora coelothrix & $83.5^{\mathrm{AB}}$ & $2.86^{\mathrm{ABC}}$ & $6.15^{\mathrm{CDE}}$ \\
\hline Ulva ohnoi & $55.2^{\mathrm{CD}}$ & $3.47^{\mathrm{AB}}$ & $6.24^{\mathrm{ABC}}$ \\
\hline Cladophora patentiramea & $48.8^{\mathrm{CD}}$ & $2.76^{\mathrm{ABC}}$ & $6.34^{\mathrm{AB}}$ \\
\hline Ulva sp. 3 & $44.4^{\mathrm{D}}$ & $3.81^{\mathrm{AB}}$ & $6.18^{\mathrm{BCDE}}$ \\
\hline Derbesia tenuissima & $85.4^{\mathrm{AB}}$ & $2.63^{\mathrm{ABC}}$ & $6.17^{\mathrm{BCDE}}$ \\
\hline \multicolumn{4}{|l|}{ Red algae } \\
\hline Halymenia floresii & $44.3^{\mathrm{D}}$ & $2.79^{\mathrm{ABC}}$ & $6.22^{\mathrm{ABCD}}$ \\
\hline Hypnea pannosa & $48.0^{\mathrm{CD}}$ & $3.93^{\mathrm{AB}}$ & $6.25^{\mathrm{ABC}}$ \\
\hline \multicolumn{4}{|l|}{ Brown algae } \\
\hline Cystoseira trinodis & $39.0^{\mathrm{D}}$ & $3.00^{\mathrm{ABC}}$ & $6.27^{\mathrm{ABC}}$ \\
\hline Padina australis & $60.2^{\mathrm{BCD}}$ & $3.19^{\mathrm{AB}}$ & $6.16^{\mathrm{CDE}}$ \\
\hline Dictyota $s p$ & $35.5^{\mathrm{D}}$ & $4.17^{\mathrm{A}}$ & $6.20^{\mathrm{BCDE}}$ \\
\hline \multicolumn{4}{|l|}{ Freshwater algae } \\
\hline Cladophora vagabunda & $82.5^{\mathrm{AB}}$ & $2.91^{\mathrm{ABC}}$ & $6.18^{\mathrm{BCDE}}$ \\
\hline Oedogonium sp. & $88.4^{\mathrm{A}}$ & $2.80^{\mathrm{ABC}}$ & $6.06^{\mathrm{DE}}$ \\
\hline Tarong polyculture & $48.8^{\mathrm{CD}}$ & $3.61^{\mathrm{AB}}$ & $6.19^{\mathrm{BCDE}}$ \\
\hline Positive control 1 & $75.2^{\mathrm{ABC}}$ & $2.64^{\mathrm{ABC}}$ & $6.03^{\mathrm{E}}$ \\
\hline Positive control 2 & $88.7^{\mathrm{A}}$ & $2.35^{\mathrm{ABC}}$ & $6.11^{\mathrm{CDE}}$ \\
\hline Negative control & $47.1^{\mathrm{D}}$ & $2.13^{\mathrm{BC}}$ & $0.080^{\mathrm{B}}$ \\
\hline SEM & 4.83 & 0.336 & 0.032 \\
\hline Effect of treatment & $*$ & * & * \\
\hline
\end{tabular}

\footnotetext{
${ }^{\mathrm{A}-\mathrm{E}}$ Means within columns with unlike superscripts $\operatorname{differ}(\mathrm{p}<0.05) ;{ }^{*} \mathrm{p}<0.001$.
}

monitor the extent that the selected algae were having a reduction effect on $\mathrm{CH}_{4}$ production. In Table 3 it is shown that Cystoseira trinodis had a significant effect in promoting $\mathrm{CH}_{4}$ reduction. The other selected algae, although showing a mild mitigation, did not reduce $\mathrm{CH}_{4}$ significantly.

There seems potential that even at low levels of inclusion $(<5 \%$ of dietary $\mathrm{OM})$ some algae have strong effect on gas production and $\mathrm{CH}_{4}$ emissions. In this in vitro study it was found that Cystoseria has potential for large $\mathrm{CH}_{4}$ reductions when applied as an additive in ruminant diets as compared to the other algae tested.

\section{Discussion}

In this study we ranked fifteen species of tropical algae for their effects on in vitro rumen gas production. We demonstrated that Cystoseira trinodis decreased in vitro total gas production with a dose-response effect compared to the other candidate algae.

Many studies have reported the composition and properties of algae in describing novel functional food ingredients [14] and many bioactive compounds have been identified in algae [13,34]. Furthermore, due to research for application as biofuels, technologies for commercial production of algae are increasingly efficient and available, and consequently feeding algae to ruminants is increasingly viable [35]. More research is required to demonstrate, confirm, and elucidate what various algae technologies and products can do to improve animal health, feed intake and utilization efficiency, milk and meat 
Table 3. Dose-response effects of 5 algae species on rumen fermentation characteristics in vitro over 72 hours.

\begin{tabular}{|c|c|c|c|c|c|}
\hline \multirow{2}{*}{ Algae species } & \multirow{2}{*}{ Dose (mg) } & \multicolumn{2}{|c|}{ Gas production parameters } & \multirow{2}{*}{$\mathrm{pH}$} & \multirow{2}{*}{$\frac{\mathrm{CH}_{4}}{\left(10^{-3} \mathrm{mmol} / \mathrm{mL}\right)}$} \\
\hline & & $\mathrm{A}($ gas $\mathrm{mL})$ & B (lag h) & & \\
\hline \multirow[t]{6}{*}{ Caulerpa taxifolia } & 0 & $117.5^{\mathrm{AB}}$ & $3.42^{\mathrm{A}}$ & $6.18^{\mathrm{AB}}$ & 26.6 \\
\hline & 20 & $118.2^{\mathrm{AB}}$ & $2.96^{\mathrm{A}}$ & $6.16^{\mathrm{B}}$ & 24.7 \\
\hline & 40 & $100.2^{\mathrm{AC}}$ & $4.11^{\mathrm{B}}$ & $6.19^{\mathrm{AB}}$ & -- \\
\hline & 80 & $93.4^{\mathrm{C}}$ & $3.46^{\mathrm{A}}$ & $6.16^{\mathrm{B}}$ & -- \\
\hline & 160 & $131.8^{\mathrm{B}}$ & $3.02^{\mathrm{A}}$ & $6.22^{\mathrm{A}}$ & 15.8 \\
\hline & SEM & 3.31 & 0.096 & 0.009 & 3.28 \\
\hline \multirow[t]{6}{*}{ Cystoseira trinodis } & 0 & $115.9^{\mathrm{A}}$ & $3.31^{\mathrm{AC}}$ & $6.15^{\mathrm{AC}}$ & $26.6^{\mathrm{A}}$ \\
\hline & 20 & $127.7^{\mathrm{A}}$ & $2.82^{\mathrm{BC}}$ & $6.21^{\mathrm{B}}$ & -- \\
\hline & 40 & $106.1^{\mathrm{A}}$ & $3.66^{\mathrm{A}}$ & $6.19^{\mathrm{AB}}$ & $9.1^{\mathrm{B}}$ \\
\hline & 80 & $74.5^{\mathrm{B}}$ & $2.58^{\mathrm{B}}$ & $6.13^{\mathrm{C}}$ & $5.1^{\mathrm{B}}$ \\
\hline & 160 & $80.9^{\mathrm{B}}$ & $3.34^{\mathrm{AC}}$ & $6.20^{\mathrm{ABC}}$ & -- \\
\hline & SEM & 3.54 & 0.103 & 0.01 & 3.07 \\
\hline \multirow[t]{6}{*}{ Oedogonium sp. } & 0 & 108.7 & 3.34 & $6.20^{\mathrm{A}}$ & 26.6 \\
\hline & 20 & 124.9 & 3.44 & $6.18^{\mathrm{A}}$ & 14.8 \\
\hline & 40 & 118 & 2.99 & $6.15^{\mathrm{AB}}$ & 24.3 \\
\hline & 80 & 122.6 & 3.13 & $6.18^{\mathrm{A}}$ & -- \\
\hline & 160 & 124.2 & 2.99 & $6.10^{\mathrm{B}}$ & 16.1 \\
\hline & SEM & 3.31 & 0.096 & 0.009 & 3.27 \\
\hline \multirow[t]{6}{*}{ Tarong polyculture } & 0 & 125 & 3.3 & $6.19^{\mathrm{AB}}$ & 26.6 \\
\hline & 20 & 109 & 3.39 & $6.16^{\mathrm{AB}}$ & -- \\
\hline & 40 & 112.9 & 3.45 & $6.20^{\mathrm{A}}$ & -- \\
\hline & 80 & 113.3 & 3.4 & $6.20^{\mathrm{A}}$ & 14.4 \\
\hline & 160 & 107 & 2.47 & $6.14^{\mathrm{B}}$ & 16 \\
\hline & SEM & 3.47 & 0.101 & 0.009 & 7.95 \\
\hline \multirow[t]{3}{*}{ Effects } & Algae & $* * *$ & NS & $* * *$ & NS \\
\hline & Dose & $* * *$ & NS & NS & $* *$ \\
\hline & Algae x Dose & $* * *$ & $* * *$ & $* * *$ & NS \\
\hline Positive control & & $127.0^{\mathrm{B}}$ & 3.01 & $5.96^{\mathrm{B}}$ & -- \\
\hline SEM & & 2.54 & 0.103 & 0.024 & \\
\hline
\end{tabular}

product quality, and decrease methane emissions $[15$, 36-38].

In vitro systems have long been used to screen feed additives for beneficial and detrimental potential to affect rumen digestion. The establishment of the collection of algae screened in the present study was based on natural abundance in local ecosystems and potential for production under controlled conditions. Effects induced by each algal species will depend on their composition and the nature, activity, and concentration of its bioactive components [39]. Therefore, freeze-drying was applied to maximize the preservation of bioactive properties of the products. The dosages were selected with the aim of supplying a range of algal biomass to demonstrate any effect on in vitro fermentation. The substrate diet was of lowmedium quality hay and the fermentation was higher 


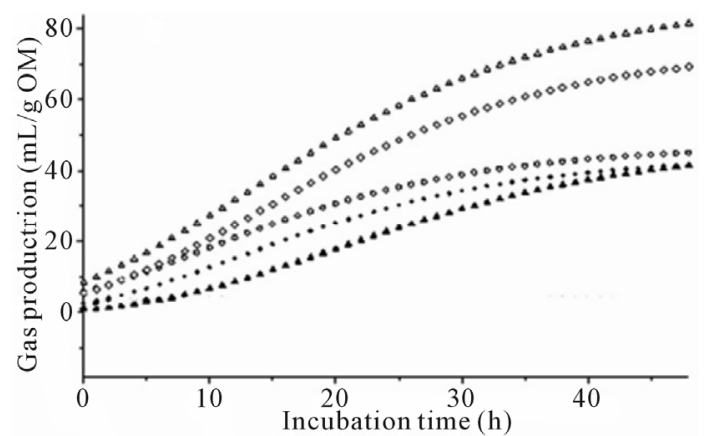

(a)

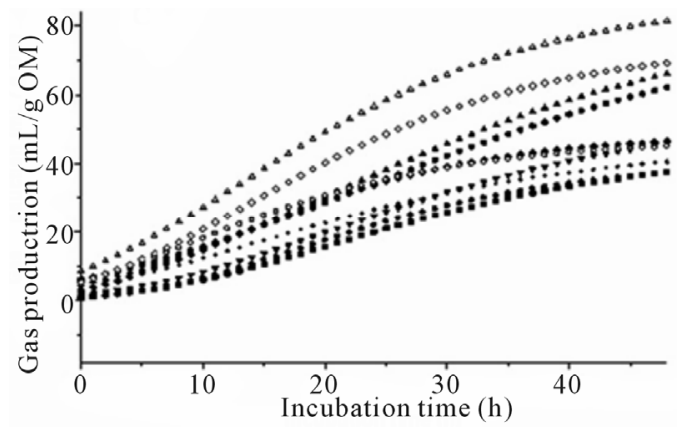

(c)

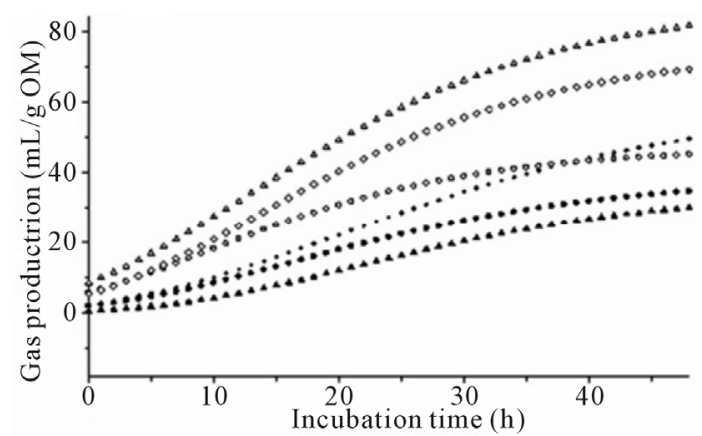

(b)

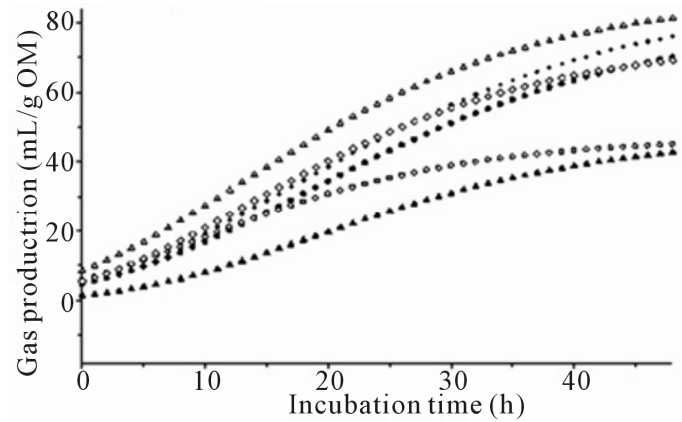

(d)

Figure 1. (a) Fermentation gas production profiles of the red algae species; Halymenia floresii $=+$; Hypnea pannosa $=\Delta$; Negative control $=\circ$; Positive control $1=\diamond$; Positive control $2=\Delta$ ). (b) Fermentation gas production profiles of the brown species; (Cystoseira trinodis $=\bullet$; Padina australis $=+$; Dictyota sp. $=\Delta$; Negative control $=\circ$; Positive control $1=\diamond$; Positive control $2=\Delta$ ). (c) Fermentation gas production profiles of the green species; (Caulerpa lentillifera $=\bullet$; Caulerpa taxifolia $=+$; Cladophora coelothrix $=\Delta ;$ Ulva ohnoi $=\nabla ;$ Cladophora patentiramea $=\bullet ;$ Ulva sp. $3=\square ;$ Derbesia tenuissima $=\bullet ;$ Negative control $=\circ$; Positive control $1=\diamond$; Positive control $2=\Delta)$. (d) Fermentation gas production profiles of the freshwater species; (Cladophora vagabunda $=\bullet ;$ Oedogonium sp. $=+$; Tarong polyculture $=\Delta$; Negative control $=\circ$; Positive control $1=\diamond ;$ Positive control $2=\Delta$ ).

with some algae than the positive control which may indicate a potential for improved feed utilization efficiency. Compared to the negative control (grass only), nine of fifteen species, and all the freshwater species, produced more blank corrected gas. The negative control contained $20 \%$ less fermentable OM, however the trend indicates a benefit to overall fermentation. As occurred with Oedogonium the overall fermentation was slightly improved over all controls in vitro and these results need elucidation in vivo. In this scenario gas and $\mathrm{CH}_{4}$ increases slightly, however this may be beneficial in tropical ruminant production under low quality feed supply as occurs in the Northern Australia dry seasons. Reduction with some, and increases with other species, suggests it may be possible to prepare appropriate doses and mixtures of algae to obtain both $\mathrm{CH}_{4}$ reduction, and maintain or improve feed utilization.

A decrease in gas production throughout the incubation was induced by the red algae compared to positive controls (Figure 1(a)). In variable levels, the red algae contain halogenated compounds, dispersed in several classes of primary and secondary metabolites including indoles, terpenes, acetogenins, phenols, fatty acids and volatile halogenated hydrocarbons [12,13,34]. Red algae have demonstrated activity against a large number of microorganisms [13].

The brown algae species also showed a lower gas production than observed with the controls (Figure 1(b)) with the exception of Padina australis that was similar to the negative control. Brown algae produce phlorotannins and a range of other natural products $[12,13,40]$. This less familiar form of tannins consists of polymers of phloroglucinol units and is exclusive to the brown algae. Tannins have been extensively studied with regard to their effects on ruminant nutrition. Dietary tannins have been reported to decrease utilization of nutrients directly inhibiting microbial activity or indirectly by forming complexes with the nutrients [41]. The present study is in agreement with the observations of Wang et al. [15] who experimented with extracts of the brown algae Ascophyllum and reported gas and $\mathrm{CH}_{4}$ reduction from rumen in vitro cultures.

The effects of the green and freshwater algae on in vitro rumen fermentation and gas reduction were less prominent (Figure 1(c) and Figure 1(d)) and some species may increase gas production (Table 2). Experiment 1 in- 
dicated gas reduction due to the inclusion of Ulva ohnoi, and antibacterial activity was previously reported in the green algae $[12,13]$ which may have affected rumen fauna leading to the slightly lower observed gas production from these species in the present study. Some green algae had a very high level of protein content which as an additive could increase gas production compared to the other algae only if it was in addition to the carbohydrate fraction. Generally, protein as a replacement to fiber would reduce total gas production [42] but as a replacement to lipid would increase gas production.

The complete nutritional and chemical composition of each species of algae is not reported here, however at this high level of inclusion ( $20 \%$ of OM) the algae adds significantly to the overall nutrient profile. This could contribute the high gas production observed with Derbesia tenuissima and Cladophora coelothrix which have high CP (Table 1). Further study is required to determine the impacts on feed intake and feed efficiency of algae, dosage, and species combinations.

Based on the results of experiment 1 and the properties of the algae, four species were selected for experiment 2 (Caulerpa taxifolia, Cystoseira trinodis, Oedogonium sp., and Tarong polyculture). Five algae OM doses were applied $(0,20,40,80,160 \mathrm{mg} / \mathrm{g}$ substrate $\mathrm{OM})$ and incubated with rumen digesta for $72 \mathrm{~h}$.

Cystoseira trinodis demonstrated a dose-response effect with increasing dosage. Cystoseira has been studied for antimicrobial compounds and terpenes have been reported to be responsible as the main compounds in the antimicrobial activity [43]. A large number of secondary metabolites have also been discovered in the order Caulerpales [44] and could contribute to the decrease in the gas production with inclusion of Caulerpa taxifolia in experiment 1 , however a dose response was not evident in experiment 2.

Methane production was monitored in some of the incubations from each of the candidate algae in experiment 2 after $72 \mathrm{~h}$ of incubation. It was not clear the precise dose response toward $\mathrm{CH}_{4}$ abatement in vitro in this experiment and samples were not successfully collected from all incubations, however the effect of the algae was clear in general terms. As a dietary inclusion Oedogonium sp., Caulerpa taxifolia, and Tarong polyculture did not show clear effect on $\mathrm{CH}_{4}$ production and did not show significant reductions. However, relative to control some $\mathrm{CH}_{4}$ reduction was indicated for all algae species tested.

Cystoseira trinodis decreased methane production at the monitored doses by up to $80 \%$. These are remarkable reductions in $\mathrm{CH}_{4}$ and the effects on overall fermentation need to be further elucidated. It would be highly beneficial from the perspectives of environmental impact of ruminant livestock products and feed utilization efficiency if algae type and species effects were combined with low or nil negative effects on fermentation and animal health. This may be feasible with appropriate dosage and species combinations.

\section{Conclusions}

Cystoseira trinodis significantly reduced methane production, and had moderate effect on total gas compared to incubations with grass only during in vitro ruminal fermentation. This suggests that $\mathrm{CH}_{4}$ reduction can be mitigated by algae with variable effects on overall fermentation. As expected, some species of algae have greater effect on gas production than others and the effects can be tempered by dosage management. For in vivo scenarios feeding of large amounts of algae may be cumbersome and expensive, lower doses are always more feasible and less likely to cause animal welfare issues.

It has been demonstrated in this study that all classes of algae have candidate members with potential to assist in ruminant feeding for improved gas production, fermentation management, and $\mathrm{CH}_{4}$ abatement. It is clear that more researches are required to fully describe the mechanisms, optimal dosage, and algae species that will best achieve the goal of a dietary supplement with both nutritional (production) and environmental benefits.

\section{REFERENCES}

[1] ABARE, "Australian Beef 06.1: Australian Beef Industry: Financial Performance for 2005-2006," ABARE, Canberra, 2006.

[2] E. Charmley, M. L. Stephens and P. M. Kennedy, "Predicting Livestock Productivity and Methane Emissions in Northern Australia: Development of a Bio-Economic Modelling Approach," Australian Journal of Experimental Agriculture, Vol. 48, No. 1-2, 2008, pp. 109-113.

http://dx.doi.org/10.1071/EA07264

[3] M. T. Abberton, A. H. Marshall, M. W. Humphreys, J. H. Macduff, R. P. Collins and C. L. Marley, "Genetic Improvement of Forage Species to Reduce the Environmental Impact of Temperate Livestock Grazing Systems," Advances in Agronomy, Vol. 98, 2008, pp. 311-355. http://dx.doi.org/10.1016/S0065-2113(08)00206-X

[4] N. W. Tomkins, S. M. Colegate and R. A. Hunter, "A Bromochloromethane Formulation Reduces Enteric Methanogenesis in Cattle Fed Grain-Based Diets," Animal Production Science, Vol. 49, No. 12, 2009, pp. 10531058. http://dx.doi.org/10.1071/EA08223

[5] Y. Kobayashi, "Abatement of Methane Production from Ruminants: Trends in the Manipulation of Rumen Fermentation," Asian-Australasian Journal of Animal Sciences, Vol. 23, No. 3, 2010, pp. 410-416.

[6] T. T. Tiemann, P. Avila, G. Ramírez, C. E. Lascano, M. Kreuzer and H. D. Hess, "In Vitro Ruminal Fermentation of Tanniniferous Tropical Plants: Plant-Specific Tannin Effects and Counteracting Efficiency of Peg," Animal Feed Science and Technology, Vol. 146, No. 3-4, 2008, 
pp. 222-241. http://dx.doi.org/10.1016/j.anifeedsci.2007.12.009

[7] B. Pen, C. Sar, B. Mwenya, K. Kuwaki, R. Morikawa and J. Takahashi, "Effects of Yucca Schidigera and Quillaja Saponaria Extracts on in Vitro Ruminal Fermentation and Methane Emission," Animal Feed Science and Technology, Vol. 129, No. 3-4, 2006, pp. 175-186. http://dx.doi.org/10.1016/j.anifeedsci.2006.01.002

[8] S. M. McGinn, K. A. Beauchemin, T. Coates and D. Colombatto, "Methane Emissions from Beef Cattle: Effects of Monensin, Sunflower Oil, Enzymes, Yeast, and Fumaric Acid," Journal of Animal Science, Vol. 82, No. 11, 2004, pp. 3346-3356.

[9] D. Macheboeuf, D. P. Morgavi, Y. Papon, J. L. Mousset and M. Arturo-Schaan, "Dose-Response Effects of Essential Oils on in Vitro Fermentation Activity of the Rumen Microbial Population," Animal Feed Science and Technology, Vol. 145, No. 1-4, 2008, pp. 335-350. http://dx.doi.org/10.1016/j.anifeedsci.2007.05.044

[10] D. N. Kamra, N. Agarwal and L. C. Chaudhary, "Inhibition of Ruminal Methanogenesis by Tropical Plants Containing Secondary Compounds," International Congress Series, Vol. 1293, 2006, pp. 156-163. http://dx.doi.org/10.1016/j.ics.2006.02.002

[11] N. Paul and C. K. Tseng, "Seaweed," In: J. S. Lucas and P. C. Southgate, Eds., Aquaculture: Farming Aquatic Animals and Plants, 2nd Edition, Blackwell Publishing Ltd., Oxford, 2012, pp. 268-284.

[12] J. W. Blunt, B. R. Copp, M. H. Munro, P. T. Northcote and M. R. Prinsep, "Marine Natural Products," Natural Product Reports, Vol. 28, No. 2, 2011, pp. 196-268. http://dx.doi.org/10.1039/c005001f

[13] J. W. Blunt, B. R. Copp, R. A. Keyzers, M. H. Munro and M. R. Prinsep, "Marine Natural Products," Natural Product Reports, Vol. 30, No. 2, 2013, pp. 237-323. http://dx.doi.org/10.1039/c2np20112g

[14] M. Plaza, A. Cifuentes and E. Ibanez, "In the Search of New Functional Food Ingredients from Algae," Trends in Food Science \& Technology, Vol. 19, No. 1, 2008, pp. 31-39. http://dx.doi.org/10.1016/j.tifs.2007.07.012

[15] Y. Wang, Z. Xu, S. J. Bach and T. A. McAllister, "Effects of Phlorotannins from Ascophyllum Nodosum (Brown Seaweed) on in Vitro Ruminal Digestion of Mixed Forage or Barley Grain," Animal Feed Science and Technology, Vol. 145, No. 1, 2008, pp. 375-395. http://dx.doi.org/10.1016/j.anifeedsci.2007.03.013

[16] A. N. Pell and P. Schofield, "Computerized Monitoring of Gas Production to Measure Forage Digestion in Vitro," Journal of Dairy Science, Vol. 76, No. 4, 1993, pp. 10631073.

http://dx.doi.org/10.3168/jds.S0022-0302(93)77435-4

[17] J. W. Cone, A. H. van Gelder, G. J. W. Visscher and L. Oudshoorn, "Influence of Rumen Fluid and Substrate Concentration on Fermentation Kinetics Measured with a Fully Automated Time Related Gas Production Apparatus," Animal Feed Science and Technology, Vol. 61, No. 1-4, 1996, pp. 113-128. http://dx.doi.org/10.1016/0377-8401(96)00950-9

[18] R. M. Mauricio, F. L. Mould, M. S. Dhanoa, E. Owen, K.
S. Channa and M. K. Theodorou, "A Semi-Automated in Vitro Gas Production Technique for Ruminant Feedstuff Evaluation," Animal Feed Science and Technology, Vol. 79, No. 4, 1999, pp. 321-330.

http://dx.doi.org/10.1016/S0377-8401(99)00033-4

[19] W. F. Pellikaan, W. H. Hendriks, G. Uwimana, L. J. G. M. Bongers, P. M. Becker and J. W. Cone, "A Novel Method to Determine Simultaneously Methane Production During in Vitro Gas Production Using Fully Automated Equipment," Animal Feed Science and Technology, Vol. 168, No. 3-4, 2011, pp. 196-205.

http://dx.doi.org/10.1016/j.anifeedsci.2011.04.096

[20] NHMRC, "Australian Code of Practice for the Care and Use of Animals for Scientific Purposes, 7th Ed.," NHRMC, Canberra, 2004.

[21] G. Getachew, P. H. Robinson, E. J. DePeters and S. J. Taylor, "Relationships between Chemical Composition, Dry Matter Degradation and in Vitro Gas Production of Several Ruminant Feeds," Animal Feed Science and Technology, Vol. 111, No. 1, 2004, pp. 57-71. http://dx.doi.org/10.1016/S0377-8401(03)00217-7

[22] I. C. S. Bueno, S. L. S. Cabral, S. P. Gobbo, H. Louvandini, D. Vitti and A. L. Abdalla, "Influence of Inoculum Source in a Gas Production Method," Animal Feed Science and Technology, Vol. 123, Part 1, 2005, pp. 95-105. http://dx.doi.org/10.1016/j.anifeedsci.2005.05.003

[23] A. T. Adesogan, N. K. Krueger and S. C. Kim, "A Novel, Wireless, Automated System for Measuring Fermentation Gas Production Kinetics of Feeds and Its Application to Feed Characterization," Animal Feed Science and Technology, Vol. 123, Part 1, 2005, pp. 211-223. http://dx.doi.org/10.1016/j.anifeedsci.2005.04.058

[24] R. J. Lawton, L. Mata, R. de Nys and N. A. Paul, "Algal Bioremediation of Waste Waters from Land-Based Aquaculture Using Ulva: Selecting Target Species and Strains," Plos One, Vol. 8, No. 10, 2013, pp. e77344. http://dx.doi.org/10.1371/journal.pone.0077344

[25] R. J. Lawton, R. de Nys and N. A. Paul, "Selecting Reliable and Robust Freshwater Macroalgae for Biomass Applications," Plos One, Vol. 8, No. 5, 2013, pp. e64168. http://dx.doi.org/10.1371/journal.pone.0064168

[26] G. Marten and R. Barnes, "Prediction of Energy Digestibility of Forages with in Vitro Rumen Fermentation and Fungal Enzyme Systems," IDRC, Ottawa, 1980.

[27] VSN International, "Genstat Release 12.2 Statistical Software,” VSN International Ltd., Hemel Hempstead, 2006.

[28] J. E. Bidlack and D. R. Buxton, "Content and Deposition Rates of Cellulose, Hemicellulose, and Lignin during Regrowth of Forage Grasses and Legumes," Canadian Journal of Plant Science, Vol. 72, No. 3, 1992, pp. 809-818. http://dx.doi.org/10.4141/cjps92-097

[29] A. Lavrencic, B. Stefanon and P. Susmel, "An Evaluation of the Gompertz Model in Degradability Studies of Forage Chemical Components," Animal Science, Vol. 64, 1997, pp. 423-431. http://dx.doi.org/10.1017/S1357729800016027

[30] R. R. Noguera, E. O. Saliba and R. M. Maurico, “Comparacion De Modelos Matematicos Para Estimar Los Parametros De Degradacion Obtenidos a Traves De La Tec- 
nica De Produccion De Gas," Revista Colombiana Ciencias Pecuarias, Vol. 20, 2004, pp. 141-148.

[31] J. M. W. Beuvink, S. F. Spoelstra and R. J. Hogendorp, "An Automated-Method for Measuring Time-Course of Gas-Production of Feedstuffs Incubated with Buffered Rumen Fluid," Netherlands Journal of Agricultural Science, Vol. 40, No. 4, 1992, pp. 401-407.

[32] M. H. Zwietering, I. Jongenburger, F. M. Rombouts and K. Vantriet, "Modeling of the Bacterial-Growth Curve," Applied and Environmental Microbiology, Vol. 56, No. 6, 1990, pp. 1875-1881.

[33] SAS Institute Inc, “Sas/Stat ${ }^{\circledR} 9.3$ User's Guide," SAS Institute Inc., Cary, 2011.

[34] S. L. Holdt and S. Kraan, "Bioactive Compounds in Seaweed: Functional Food Applications and Legislation," Journal of Applied Phycology, Vol. 23, No. 3, 2011, pp. 543-597. http://dx.doi.org/10.1007/s10811-010-9632-5

[35] D. F. A. Costa, P. I. Isherwood, S. R. McLennan, D. P. Poppi and S. P. Quigley, "Chemical Composition and in Vitro Degradability of Various Algae Species and Protein Supplements Commonly Fed to Ruminants," Animal Production in Australia, Vol. 28, 2010, p. 61

[36] S. J. Bach, Y. Wang and T. A. McAllister, "Effect of Feeding Sun-Dried Seaweed (Ascophyllum Nodosum) on Fecal Shedding of Escherichia Coli O157:H7 by Feedlot Cattle and on Growth Performance of Lambs," Animal Feed Science and Technology, Vol. 142, No. 1-2, 2008, pp. 17-32. http://dx.doi.org/10.1016/j.anifeedsci.2007.05.033

[37] K. E. Saker, J. H. Fike, H. Veit and D. L. Ward, "Brown Seaweed-(Tasco) Treated Conserved Forage Enhances Antioxidant Status and Immune Function in Heat-Stressed Wether Lambs," Journal of Animal Physiology and Animal Nutrition (Berlin), Vol. 88, No. 3-4, 2004, pp. 122-30. http://dx.doi.org/10.1111/j.1439-0396.2003.00468.x
[38] V. G. Allen, K. R. Pond, K. E. Saker, J. P. Fontenot, C. P. Bagley, R. L. Ivy and D. B. Wester, "Tasco-Forage: III. Influence of a Seaweed Extract on Performance, Monocyte Immune Cell Response, and Carcass Characteristics in Feedlot-Finished Steers," Journal of Animal Science, Vol. 79, No. 4, 2001, pp. 1032-1040.

[39] N. A. Paul, R. de Nys and P. D. Steinberg, "Chemical Defence against Bacteria in the Red Alga Asparagopsis Armata: Linking Structure with Function," Marine Ecology Progress Series, Vol. 306, 2006, pp. 87-101. http://dx.doi.org/10.3354/meps306087

[40] S. Gupta and N. Abu-Ghannam, "Bioactive Potential and Possible Health Effects of Edible Brown Seaweeds," Trends in Food Science \& Technology, Vol. 22, No. 6, 2011, pp. 315-326. http://dx.doi.org/10.1016/j.tifs.2011.03.011

[41] B. R. Min, T. N. Barry, G. T. Attwood and W. C. McNabb, "The Effect of Condensed Tannins on the Nutrition and Health of Ruminants Fed Fresh Temperate Forages: A Review," Animal Feed Science and Technology, Vol. 106, No. 1-4, 2003, pp. 3-19. http://dx.doi.org/10.1016/S0377-8401(03)00041-5

[42] J. W. Cone and A. H. van Gelder, "Influence of Protein Fermentation on Gas Production Profiles," Animal Feed Science and Technology, Vol. 76, No. 3-4, 1999, pp. 251264. http://dx.doi.org/10.1016/S0377-8401(98)00222-3

[43] V. Amico, "Marine Brown Algae of Family Cystoseiraceae: Chemistry and Chemotaxonomy," Phytochemistry, Vol. 39, No. 6, 1995, pp. 1257-1279. http://dx.doi.org/10.1016/0031-9422(95)00199-H

[44] V. J. Paul and W. Fenical, "Chemical Defense in Tropical Green-Algae, Order Caulerpales," Marine Ecology Progress Series, Vol. 34, No. 1-2, 1986, pp. 157-169. http://dx.doi.org/10.3354/meps034157 